\title{
Numerical evaluation on steep soil-nailed slope using finite element method
}

\author{
Panyabot Kaothon, Kean Thai Chhun and Chan-Young Yune*
}

\section{${ }^{*}$ Correspondence:}

yune@gwnu.ac.kr Department of Civil

Engineering, GangneungWonju National University, Gangneung-si, Gangwon-do 25457, Republic of Korea

\begin{abstract}
In conventional design of soil-nailed slope, the nail parameters such as nail spacing $(1-2 \mathrm{~m})$, and nail inclination $\left(10^{\circ}-20^{\circ}\right)$ have been recommended without considering any specific slope angle. Henceforth, this paper presents a numerical evaluation on the soil-nailed slope with flexible facing based on the finite element method in order to investigate the range of those two parameters with any size of nail head in various slope angles $\left(45^{\circ}, 55^{\circ}, 65^{\circ}\right.$, and $\left.75^{\circ}\right)$. Based on a minimum factor of safety ( $F S_{\min }$ $=1.5)$, the analysis results indicated that the suggested range of those parameters in the conventional specification was applicable in the slope angle of $45^{\circ}$ and $55^{\circ}$ with any sizes of nail head. Nevertheless, it was not practical for slope angle of $65^{\circ}$ and $75^{\circ}$, which required the size of nail head at least $400 \times 400 \times 250 \mathrm{~mm}$, with nail spacing less than or equal to $1.5 \mathrm{~m}$, and nail inclination from $5^{\circ}$ to $10^{\circ}$.
\end{abstract}

Keywords: Nail spacing, Nail inclination, Nail head, Slope angle, Global factor of safety, Finite element method

\section{Introduction}

Soil nailing is a slope stabilizing technique that is commonly used to reinforce in-situ ground by interacting with soil. The slope stabilization using nails is achieved by inserting reinforcing bars in the soil, which is then grouted, fixed soundly to the ground for their entire length and finally a flexible or rigid facing is installed. The influencing parameters for soil nails on slope stability consist of (1) the type of soil, (2) slope inclination, (3) nail inclination, (4) nail length, (5) horizontal nail spacing, (6) vertical nail spacing, (7) nail diameter, and (8) nail head size. In previous studies about soil nails, many researchers have used various methods to study the effectiveness of soil nail on slope stability. Particularly, limit equilibrium method (LEM), finite element method (FEM), and finite different method (FDM) are the common techniques to analyze slope stability.

LEM is currently the typical stability analysis and still has been used widely in recent research $[8,11,13,20,25]$. The result from those studies showed that the factor of safety initially increased with the increase of nail inclination until reaching the optimum inclination angle and then steadily decreased. Also, the position of nails can influence the stability of a soil-nailed slope. author(s) and the source, provide a link to the Creative Commons licence, and indicate if changes were made. The images or other third party material in this article are included in the article's Creative Commons licence, unless indicated otherwise in a credit line to the material. If material is not included in the article's Creative Commons licence and your intended use is not permitted by statutory regulation or exceeds the permitted use, you will need to obtain permission directly from the copyright holder. To view a copy of this licence, visit http:// creativecommons.org/licenses/by/4.0/. 
Finite element or difference analysis is more rigorous numerical simulation based on stress-strain relation of a ground. For the analysis of slope stability with soil nails, the shear strength reduction method can be adopted in FEM to estimate the factor of safety. The numerical analysis for soil nail structure by using FEM or FDM has been studied by numerous researchers $[7,16,19,21,22,26]$. These studies reported that increasing nail inclination could decrease the maximum tensile force in each nail, and the nail head could prevent local failure between nails. Moreover, the increased horizontal spacing caused increased horizontal deflection and vertical settlement. On the contrary, horizontal deflection and vertical settlement can be decreased with the increase of nail length.

Most of the previous research have focused on the individual effect of soil nail parameters in the range of the design specification and only the possible range of nail spacing, and nail inclination were suggested for the construction work without considering any specific slope angles $[3,4,18]$. The combined effect between nail head size and other nail parameters, however, hasn't been studied much. Thus, the objective of this paper was to evaluate the soil-nailed slope with flexible facing in the outer range of design specification based on the finite element method. The variation of slope inclination $(\alpha)$, nail inclination $(\beta)$, horizontal spacing $\left(S_{h}\right)$, vertical spacing $\left(S_{v}\right)$, and nail head size $\left(n_{h}\right)$ were examined in this study and the slope stability was analyzed with the minimum safety factor in reinforced slope conditions. The outcome of this study offers useful information for securing the global stability of the steep soil-nailed slope.

\section{Conventional specification}

\section{Slope geometry}

For flexible facing systems, the soil-nailed structure was recommended to be applied on a slope steeper than $45^{\circ}$ with various cohesive soils [1], $68^{\circ}$ with Mercia mudstone group, and firm to stiff sandy clay [14]. Also, for the steeper slope about $70^{\circ}$, it was applicable when the soil type is silty clay and clayey sand [17].

\section{Nail parameters}

The soil nails are typically installed at slopes with an angle of $10^{\circ}-20^{\circ}$ to allow the grout flow from the top to the bottom of the drill hole. Additionally, nail angles less than $10^{\circ}$ was not recommended to protect the grout flowing out and an extended "bird's beak" at nail head [4].

Nail spacing has two directions $\left(S_{h}\right.$ and $\left.S_{v}\right) . S_{h}$ is generally decided as the same as $S_{v}$ (square pattern of nails) in the design stage. Phear et al. [18] indicated that the interval of nails from 1 to $2 \mathrm{~m}$ should be considered. In addition, Carlos et al. [4] suggested that the first and the bottom row of nails should be installed with approximately $0.6-1.06 \mathrm{~m}$ spacing from the top of a slope and $0.6-0.9 \mathrm{~m}$ above the base of a slope (Fig. 1). These demands are the consequence of the limited ability of nail head to work as a cantilever.

To analyze the slope stability with soil nails, the preliminary design for the length of soil nail is necessary. It can be calculated in the range of $0.8-1.2 H$, where $H$ is the height of the slope [9]. For the preliminary design, a reinforcing bar with the diameter of $32 \mathrm{~mm}$ should be adopted as a first step and can be reduced to $10 \mathrm{~mm}$ as necessary [2]. And the diameter of drill hole should be at least $125 \mathrm{~mm}$ [6]. 

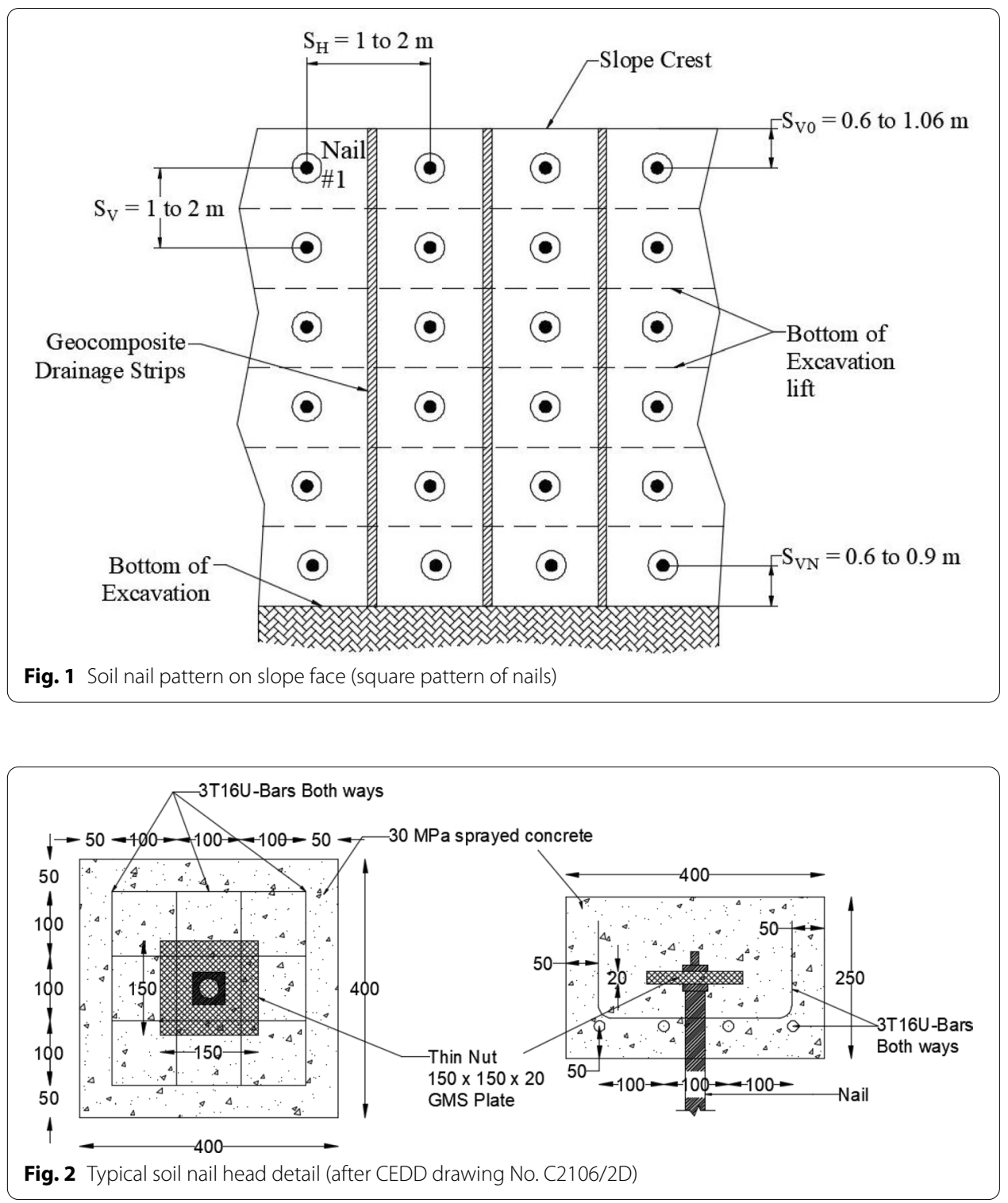

The size of nail head is also another influential component in the soil nail design. There are several design approaches on soil nail head in various countries, and most engineers indicated that nail heads could enhance the internal stability or the external stability of a nailed structure. Hong Kong and UK suggested the design criteria for the size of a nail head size with flexible facing. Those criterion gives three different nail head sizes: $400 \times$ $400 \times 250 \mathrm{~mm}, 600 \times 600 \times 250 \mathrm{~mm}$, and $800 \times 800 \times 250 \mathrm{~mm}$ [10]. The detail of soil nail head is presented in Fig. 2.

\section{Modeling}

For the simulation of slopes reinforced with nails, finite element analysis in plane strain for various slope angles $\left(45^{\circ}, 55^{\circ}, 65^{\circ}\right.$, and $\left.75^{\circ}\right)$ was conducted using Plaxis 2D. Soil nails and nail heads were simulated as the geogrid and plate elements, respectively. 
In numerical modeling, the shape of both geogrid and plate structural elements is rectangular with a width equal to $1 \mathrm{~m}$ in the perpendicular plane direction. Since the soil nail has a circular shape in cross-sectional area and nail heads are discrete square plates placed at designed horizontal spacing, it is required to determine equivalent axial and bending stiffness as circular for soil nails and square size for nail heads [19].

A reinforcing bar (soil nail) with the diameter $(d)$ and modulus of elasticity $\left(E_{n}\right)$ is placed in the drilled hole filled with cement grout which has a diameter $D_{D H}$ and a modulus of elasticity $E_{g}$. Based on these parameters, the equivalent modulus of elasticity $E_{e q}$ expressed by Babu et al. [24] in Eq. (1) was adopted.

$$
E_{e q}=E_{n}\left(\frac{A_{n}}{A}\right)+E_{g}\left(\frac{A_{g}}{A}\right)
$$

where $A_{n}$ is the cross-sectional area of reinforcement bar; $A$ is the total cross-sectional area of grout and soil nail; $A_{g}$ is the cross-sectional area of cement grout.

The equivalent axial and bending stiffness are presented in Eqs. (2-4).

For soil nail

$$
E A=\frac{E_{e q}}{S_{h}}\left(\frac{\pi D_{D H}^{2}}{4}\right)
$$

For nail-head

$$
\begin{aligned}
& E A=\frac{E}{S_{h}} t \cdot n_{h} \\
& E I=\frac{E}{12 S_{h}} t \cdot n_{h}^{3}
\end{aligned}
$$

where $n_{h}$ is the size of a square nail head; $t$ is the thickness of the nail head.

The equivalent plate diameter of nail is calculated using the formulation:

$$
d=\sqrt{12\left(\frac{E I}{E A}\right)}
$$

Typical clayey sand was assumed as the soil-nailed slope and modelled as Mohr-Coulomb material, while nails and related structural elements are simulated as elastic materials $[19,23,24]$. This is due to the high ultimate bonding strength between steel and cement grout $[12,15]$ also, the possibility of yielding is fairly low [27]. The dimensions of the model are also presented in Table 1. The horizontal and vertical displacements are fixed as zero at the bottom boundary and free at the top. The bottom boundaries were considered as drained (phreatic line). The input parameters of soil nail and in-situ soil for the modeling of slope are summarized in Tables 2, 3. A finer mesh is generated around soil nails for achieving accurate results and the surcharge of $5 \mathrm{kN} / \mathrm{m}^{2}$ is also applied to the crest of the slope. The flexible facing is chosen for modeling in which the nail head is individually connected to each nail. The finite element mesh for the modelling of the reinforced slope with nails is represented in Fig. 3. 
Table 1 Slope geometry

\begin{tabular}{lr}
\hline Description & Value \\
\hline Vertical height of slope, $H(\mathrm{~m})$ & 10 \\
Length of crest slope, $b(\mathrm{~m})$ & 9 \\
Height of ground soil, $h(\mathrm{~m})$ & 5 \\
Length of ground soil, $L(\mathrm{~m})$ & 26 \\
Slope angle, $a\left(^{\circ}\right)$ & $45,55,65,75$
\end{tabular}

Table 2 In-situ soil parameters

\begin{tabular}{ll}
\hline Parameter & Value \\
\hline Cohesion, $\mathrm{C}^{\prime}\left(\mathrm{kN} / \mathrm{m}^{2}\right)$ & 4 \\
Internal friction angle, $\varphi\left(^{\circ}\right)$ & 31.5 \\
Unit weight, $Y\left(\mathrm{kN} / \mathrm{m}^{3}\right)$ & 17 \\
Elasticity modulus, $E_{s}\left(\mathrm{kN} / \mathrm{m}^{2}\right)$ & 20 \\
Poison's ratio, $v_{s}$ & 0.30 \\
\hline
\end{tabular}

Table 3 Soil nail parameters

\begin{tabular}{lll}
\hline Description & Value & Design limitation \\
\hline Yield strength of reinforcement, $f_{y}\left(\mathrm{~N} / \mathrm{mm}^{2}\right)$ & 415 & $400-600$ \\
Elasticity modulus of reinforcement, $E_{n}(\mathrm{GPa})$ & $2,00,000$ & - \\
Elasticity modulus of grout $\left(\right.$ concrete),$E_{g}(\mathrm{GPa})$ & 22,000 & - \\
Diameter of reinforcement, $d(\mathrm{~mm})$ & 25 & $10-32$ \\
Drill hole diameter, $D_{D H}(\mathrm{~mm})$ & 150 & $\geq 125$ \\
Length of nail, $I_{n}(\mathrm{~m})$ & 8 & $0.8-1.2 \mathrm{H}$ \\
Nail inclination, $\beta\left({ }^{\circ}\right)$ & $0-25$ & 10 to 20 \\
Nail horizontal spacing, $S_{h}(\mathrm{~m})$ & $1-3$ & $1-2$ \\
Nail vertical spacing, $S_{V}(\mathrm{~m})$ & $1-3$ & $1-2$ \\
Nail head, $n_{h}(\mathrm{~m})$ & $400-800$ & $400-800$ \\
Facing thickness, $t(\mathrm{~mm})$ & 250 & 250
\end{tabular}

The factor of safety in analysis of numerical simulation can be achieved by reducing the strength parameters of the soil. This method is called Phi-c reduction or strength reduction technique. In this approach, it allows finding the factor of safety of a slope by initiating a systematic reduction sequence for the available shear strength parameters $c^{\prime}$ and $\phi^{\prime}$ just cause the slope to fail. The reduction values of shear strength parameters $c_{f}{ }^{\prime}$ and $\phi_{f}^{\prime}$ are defined as:

$$
\begin{aligned}
& c_{f}^{\prime}=\frac{c^{\prime}}{S R F} \\
& \phi_{f}^{\prime}=\tan ^{-1}\left(\frac{\tan \phi^{\prime}}{S R F}\right)
\end{aligned}
$$




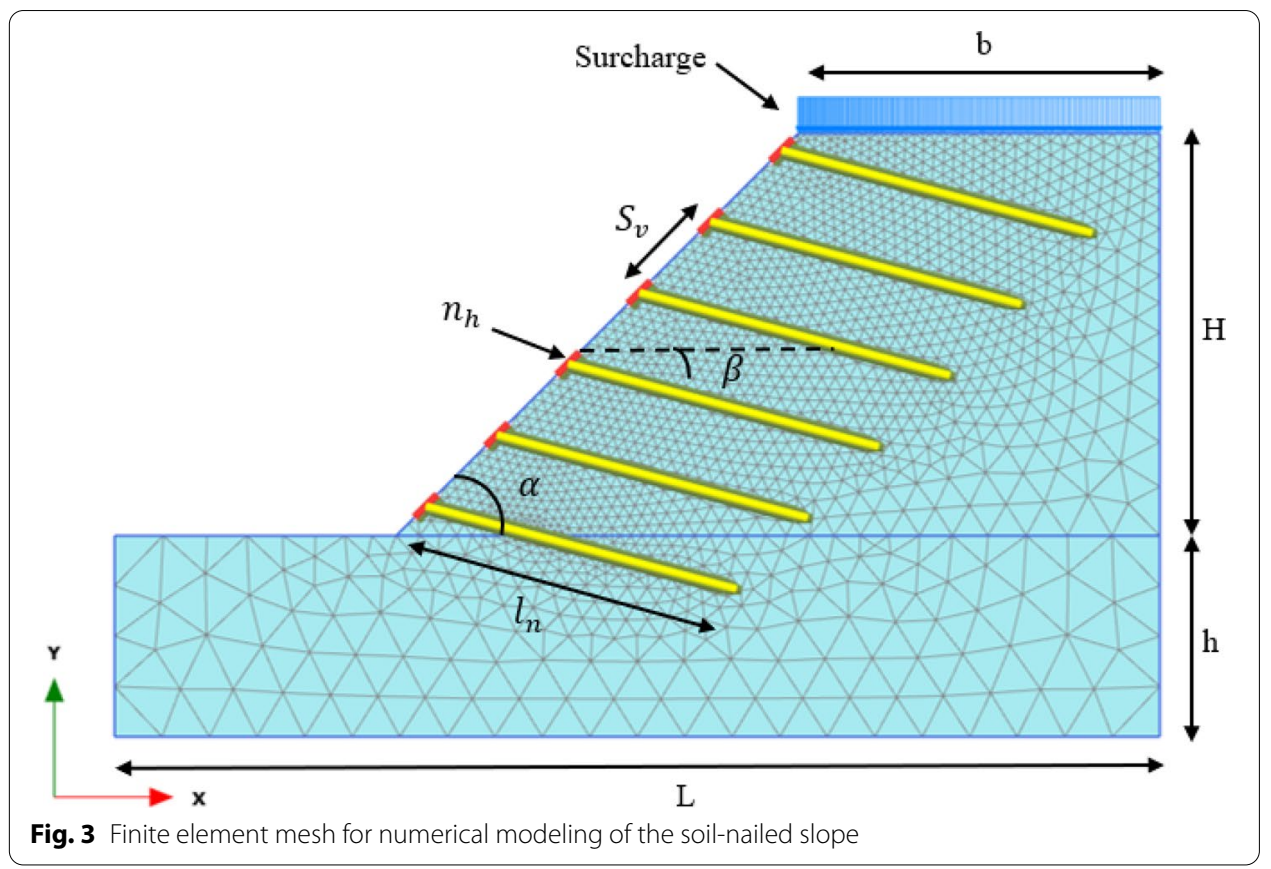

Table 4 The variation range of soil nail parameters

\begin{tabular}{llll}
\hline$a\left(\mathbf{l}^{\prime}\right)$ & $\beta\left(\mathbf{o}^{\circ}\right.$ & $S_{h}=S_{v}(\mathbf{m})$ & $n_{h}(\mathbf{m})$ \\
\hline $45,55,65,75$ & $0,5,10,15,20,25$ & $1,1.5,2,2.5,3$ & Without nail head, $0.4,0.6,0.8$ \\
\hline
\end{tabular}

in which the SRF is the strength reduction factor. The factor of safety of the slope, FS, is the value of SRF to bring the slope to failure.

\section{Numerical analysis results and discussion}

Sensitive analysis for five different slope and soil nail parameters was carried out. Considered variables in this analysis were slope inclination $(\alpha)$, nail spacing $\left(N S=S_{v}=S_{h}\right)$, nail inclination $(\beta)$, and nail head size $\left(n_{h}\right)$ are summarized in Table 4 . Since each slope angle had 120 models based on the number of each variation of parameters then 480 simulations were conducted in total. In this study, 1.5 of minimum factor of safety $\left(F S_{\text {min }}\right.$ $=1.5$ ) was chosen for the verification in the reinforced slope by soil nail [10]. And then the result of soil nailed slope stability with flexible facing systems was presented in terms of a combination of soil nail parameters.

\section{Effect of nail spacing}

To study the effect of nail spacing (NS) on the FS of the soil-nailed slope, the nail spacing in the range $1-3 \mathrm{~m}$ were investigated with fixed value of nail inclination $(\beta$ $=10^{\circ}$ ) without nail head. Figure 4 indicates the relationship between FS and nail spacing in various slope angles $\left(45^{\circ}, 55^{\circ}, 65^{\circ}\right.$, and $\left.75^{\circ}\right)$. From this figure, it is noted that $F S$ was significantly affected by both nail spacing and slope angle. This is due to the wider nail spacing could reduce number of nails which resulting in increased 


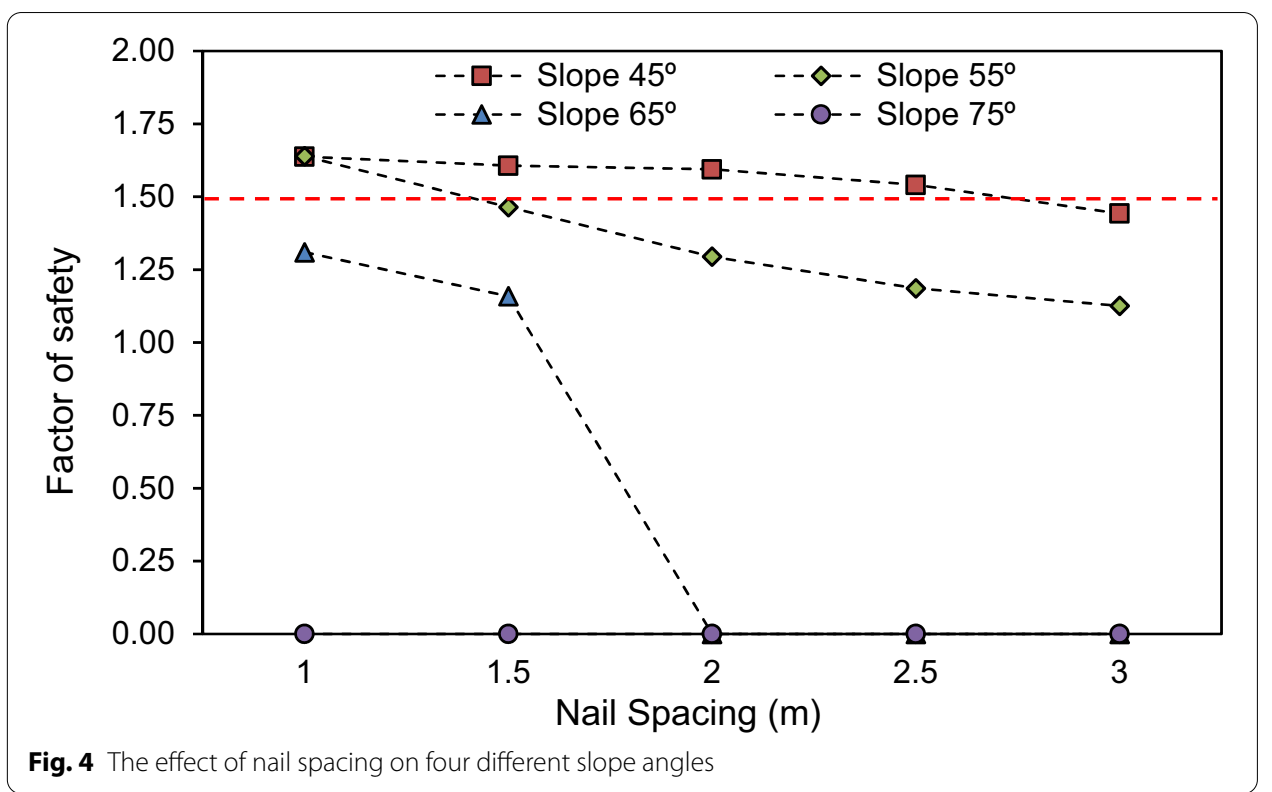

weight of soil between nails and lead to the increment of shear stress in each nail [5]. Also, local failure can occur on the slope surface [26]. Furthermore, the decreasing $F S$ was also due to the increase of critical slip failure caused by an increase of slope angle. By comparing $F S_{\text {min }}$ (Fig. 4), the $F S$ of nail spacing 1-3 $\mathrm{m}$ in all slope angles was lower than 1.5 except nail spacing from 1 to $2.5 \mathrm{~m}$ in slope $45^{\circ}$ and $N S=1 \mathrm{~m}$ in slope $55^{\circ}$. Particularly, it was proved that the validated range of nail spacing was decreased by increasing slope angle. As can be seen in steep slopes with inclination of 65 and $75^{\circ}$, the nail spacing in a range from 1 to $3 \mathrm{~m}$ was no longer valid.

\section{Effect of nail inclination}

To investigate the effect of nail inclination on the $F S$, various nail inclinations from $0^{\circ}$ to $25^{\circ}$ were considered with varying nail spacing $(1-3 \mathrm{~m})$ and slope angle $\left(45^{\circ}-\right.$ $\left.75^{\circ}\right)$. The effect of nail head was not considered, and the result was illustrated in Fig. 5. In Fig. 5a, the $F S$ was observed to increase and then decrease with an increase of nail inclination. However, the $F S$ gradually decreased for slope angle of $55^{\circ}$ with nail spacing of $2,2.5$, and $3 \mathrm{~m}$ and for all other cases with slope angle of $65^{\circ}$ and $75^{\circ}$ as shown in Fig. 5b-d. This is due to the available bonding length of the nail inserted behind the slip surface (boundary of passive and active zone). In other words, the nail orientation could allow the nails perfectly cross the potential slip surface until it reaches the optimum angle. In Fig. 5 a for slopes having $45^{\circ}$ of inclination, the optimum nail inclination $\left(\beta_{\text {opt }}\right)$ was in a range between $10^{\circ}$ and $20^{\circ}$ and it was consistent with the previous studies by Lin et al. [16] and Rotte et al. [20]. In Fig. 5b, however, the range of $\beta_{\text {opt }}$ was valid only in case of $N S=1 \mathrm{~m}$. In Fig. $5 \mathrm{c}$, d, the $F S$ was lower than 1.5 in all analysis cases because nail inclination could only provide the internal stability of slope [14]. It is obvious that the $\beta_{\text {opt }}$ is strongly influenced by the slope angle and nail spacing. 

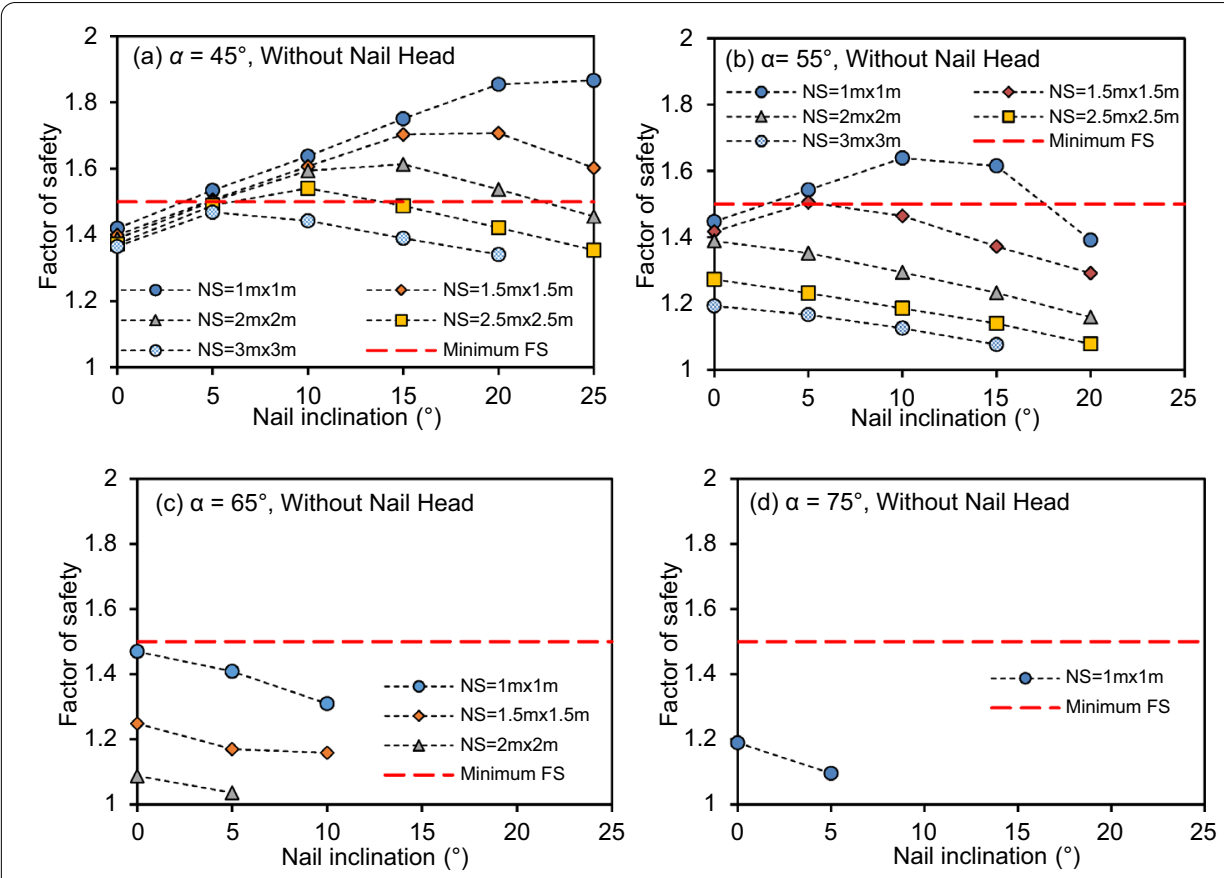

Fig. 5 The effect of nail inclination in four different slope angles
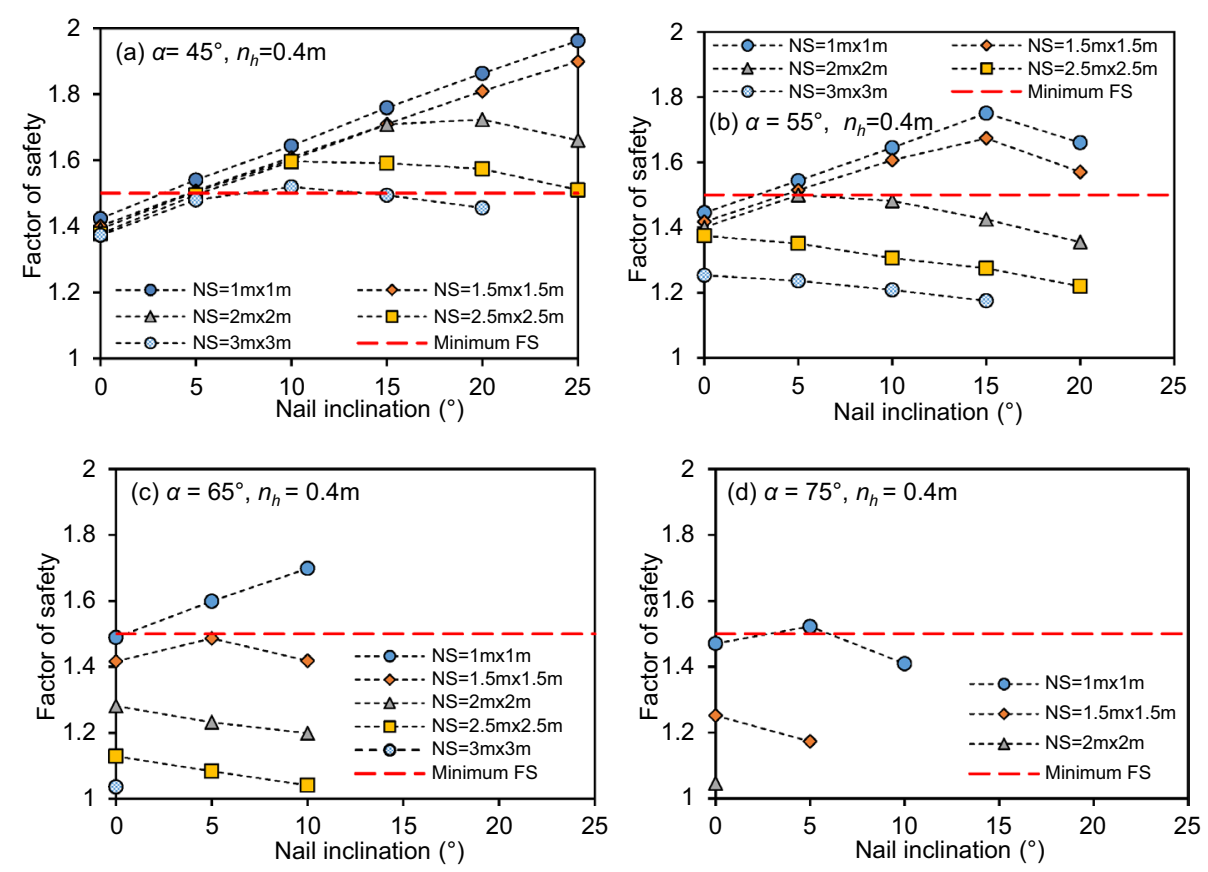

Fig. 6 The effect of nail head size equal to $0.4 \mathrm{~m}$ in four different slope angles

\section{Effect of nail head}

To evaluate the effect of nail head size on the $F S$, the various slope angle, nail spacing, nail inclination, and nail head size $(0.4-0.8 \mathrm{~m})$ was examined as presented in Figs. 68. The FS and the $\beta_{\text {opt }}$ was inversely decreased with an increase in the slope angle. 

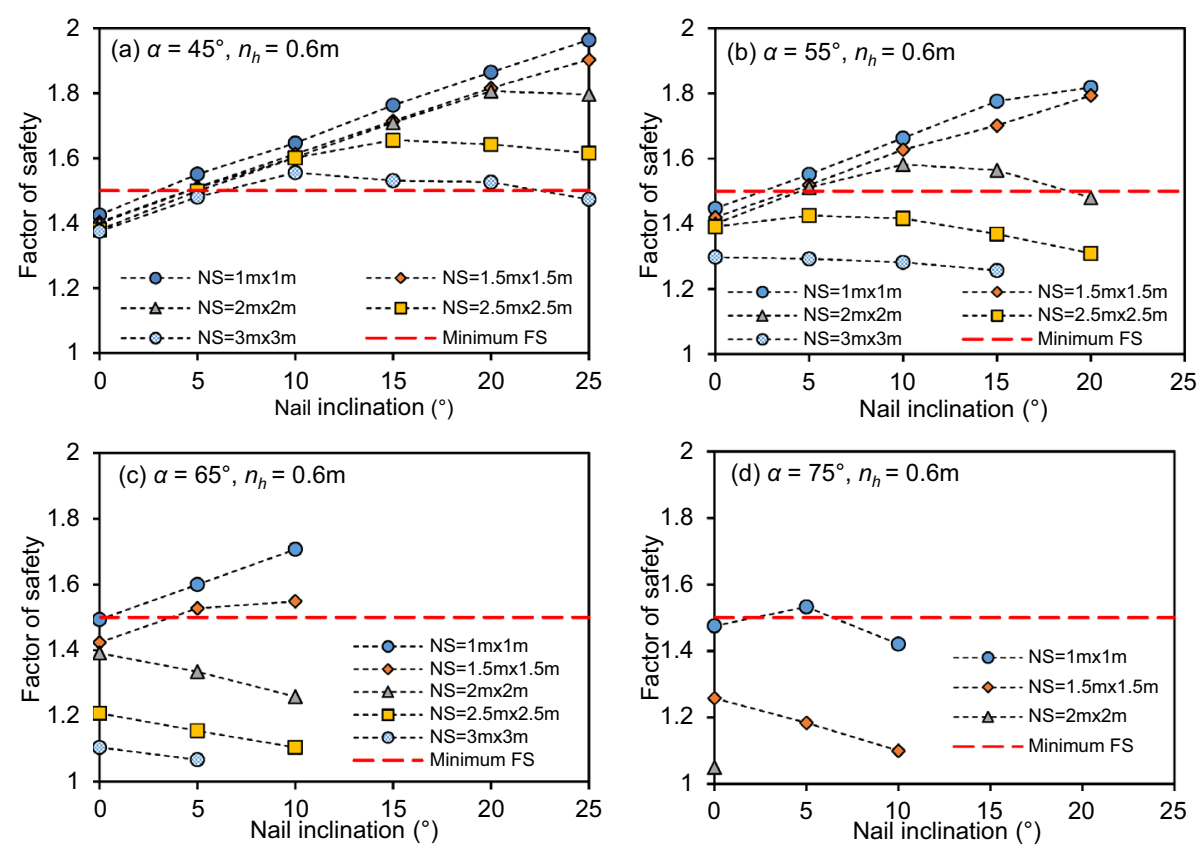

Fig. 7 The effect of nail head size equal to $0.6 \mathrm{~m}$ in four different slope angles

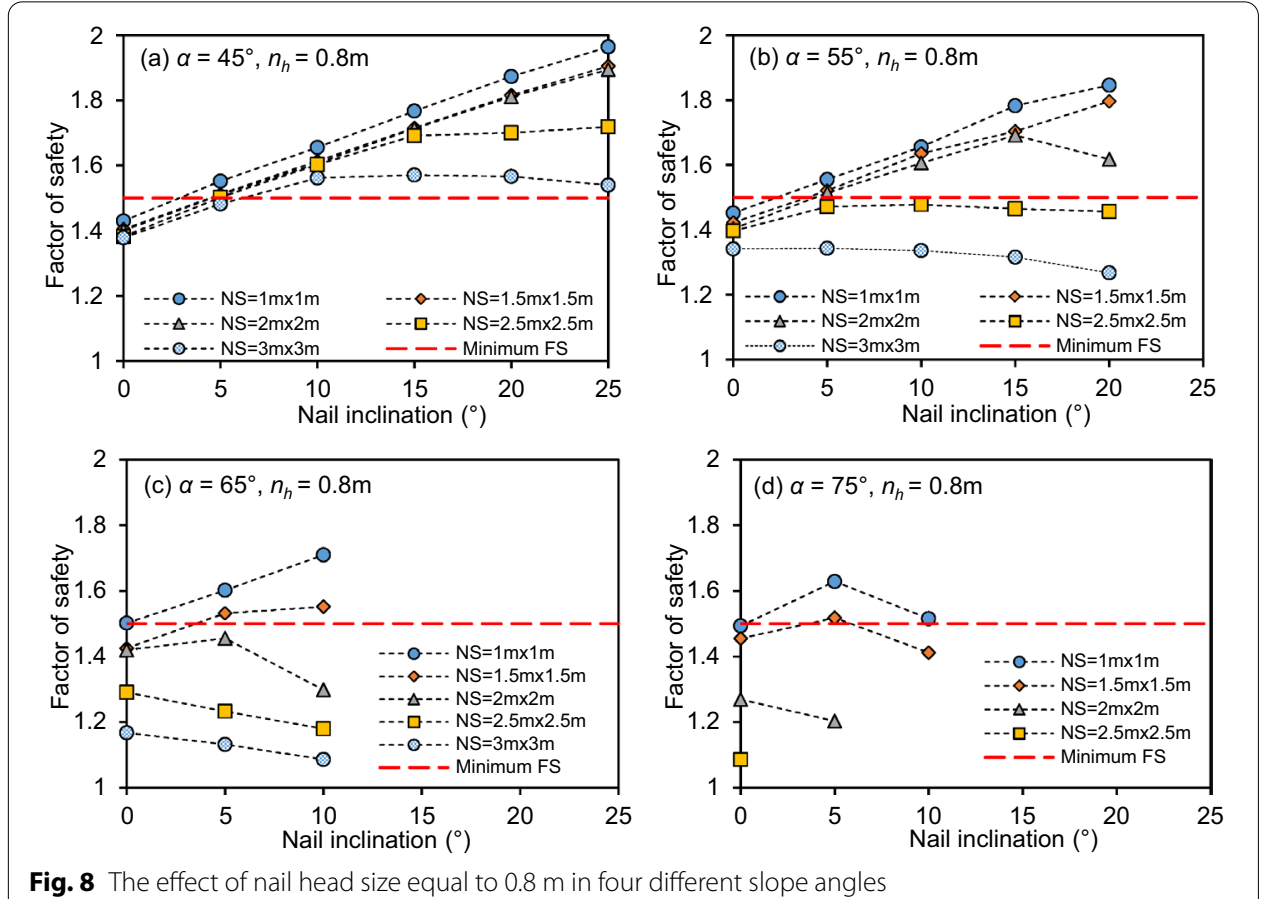

Interestingly, by analyzing with $F S_{\text {min }}$, the presence of nail head enabled the nail spacing 1 and 1.5 m workable in slope 65 and $75^{\circ}$ as shown in Figs. $6 c, d ; 7 c, d ; 8 c, d$ which were unstable without nail head. Also, as can be observed on the overall result, the flexible facing structure can be safe in a limited conditions at $75^{\circ}$ of slope angle. 

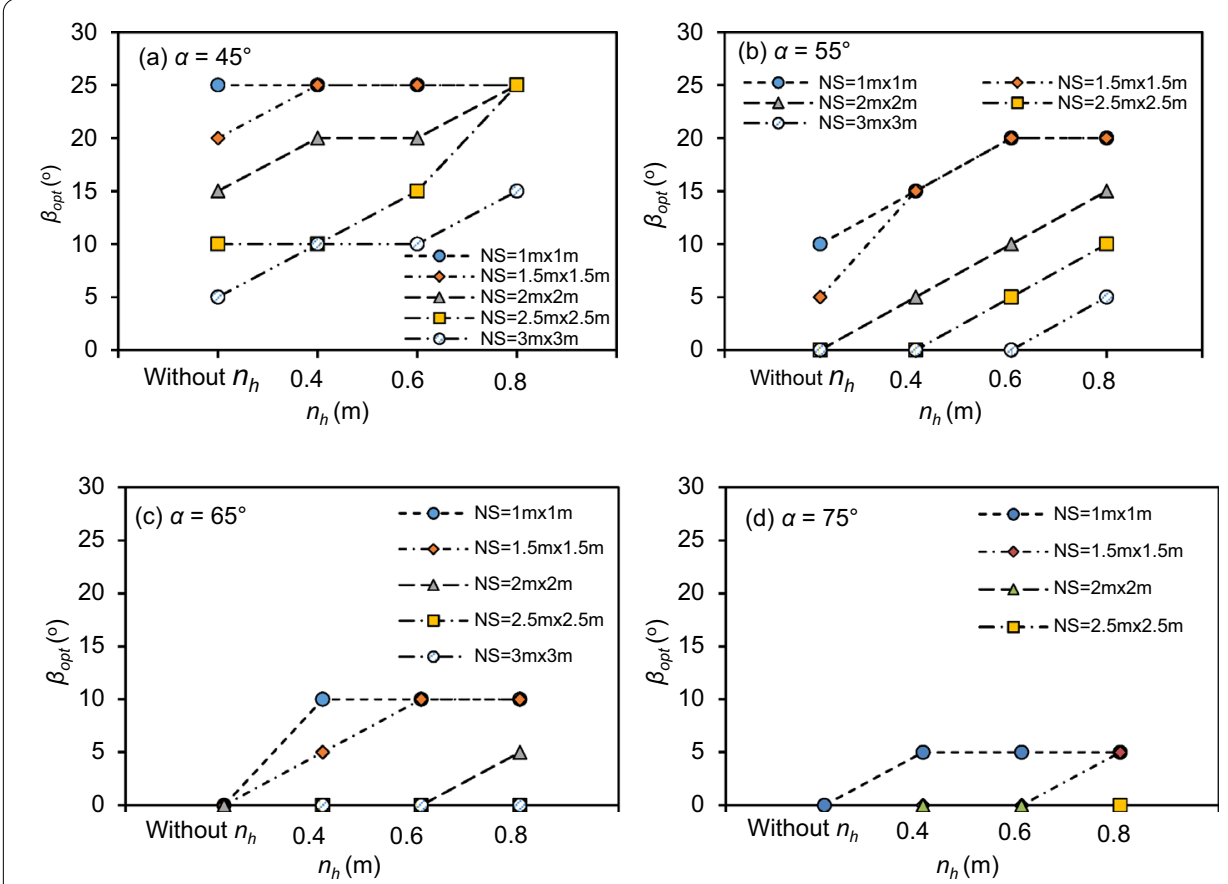

Fig. 9 The effect of nail head size on optimum nail inclination in four different slope angles

Table 5 Validation range of NS and $\beta$ in various slope angles and nail head sizes

\begin{tabular}{|c|c|c|c|c|c|c|c|c|}
\hline \multirow[t]{2}{*}{$a(\circ)$} & \multicolumn{2}{|c|}{ Without nail head } & \multicolumn{2}{|c|}{$n_{h}=0.4 \mathrm{~m}$} & \multicolumn{2}{|c|}{$n_{h}=0.6 \mathrm{~m}$} & \multicolumn{2}{|c|}{$n_{h}=0.8 \mathrm{~m}$} \\
\hline & $N S(\mathbf{m})$ & $\beta\left({ }^{\circ}\right)$ & $N S(\mathbf{m})$ & $\beta\left({ }^{\circ}\right)$ & $N S(\mathrm{~m})$ & $\left.\beta()^{\circ}\right)$ & $\overline{N S(\mathbf{m})}$ & $\beta\left({ }^{\circ}\right)$ \\
\hline \multirow[t]{4}{*}{45} & $1-1.5$ & $5-25$ & $1-2.5$ & $5-25$ & $1-2.5$ & $5-25$ & $1-2.5$ & $10-25$ \\
\hline & 2 & $5-20$ & & & & & & \\
\hline & 2.5 & $10-20$ & 3 & 10 & 3 & $10-20$ & 3 & $10-20$ \\
\hline & 3 & 10 & & & & & & \\
\hline \multirow[t]{2}{*}{55} & 1 & $5-15$ & $1-1.5$ & $5-20$ & $1-1.5$ & $5-20$ & $1-2$ & $10-20$ \\
\hline & 1.5 & 5 & & & 2 & $5-15$ & & \\
\hline 65 & - & - & 1 & $5-10$ & $1-1.5$ & $5-10$ & $1-1.5$ & $5-10$ \\
\hline \multirow[t]{2}{*}{75} & - & - & 1 & 5 & 1 & 5 & 1 & $5-10$ \\
\hline & & & & & & & 1.5 & 5 \\
\hline
\end{tabular}

The $\beta_{\text {opt }}$ were found to increase with an increase in the nail head size (Fig. 9). It indicated that the nail head can contribute to the global stability of the slope by working as a reaction plate which compresses the surface soil of slope (active zone) and produces tensile force in nail and also can prevent the local failure between nails. This result was consistent with the previous study by Shiu and Chang [21].

Table 5 shows the validation range of nail spacing $(N S)$ and nail inclination $(\beta)$ in various slope angles and nail head sizes based on Figs. $6-8$. From this, it is found that the conventional specification ( $N S=1-2 \mathrm{~m}$ and $\beta=10^{\circ}-20^{\circ}$ ) is practical in slopes in angle of $45^{\circ}$ and $55^{\circ}$. Whereas, those ranges cannot be applied to slopes in angle of $65^{\circ}$ and $75^{\circ}$. Thus, to stabilize those two steep slopes $\left(65^{\circ}\right.$ and $\left.75^{\circ}\right)$ with soil nails, nail 
head should be considered having dimensions at least $n_{h}$ of $0.4 \mathrm{~m}$ with nail spacing less than or equal to $1.5 \mathrm{~m}$, and nail inclination from $5^{\circ}$ to $10^{\circ}$.

\section{Conclusions}

In this study, the numerical modeling of the soil-nailed slope was conducted using FEM. Effect of slope angle, nail spacing, nail inclination, and nail head size on the slope stability was numerically investigated. Based on these analysis results, the following conclusion can be drawn:

- By increasing the nail spacing (NS), the FS of the soil-nailed slope decreased due to the large spacing induced the increment weight of soil between nails, and the less amount of nails results in the external failure of slope. Furthermore, the range of NS decreased with an increase in slope angle $(\alpha)$. This because of an increase of critical slip failure in slope.

- The numerical results indicated the optimum nail inclination $\left(\beta_{\text {opt }}\right)$ in a range between $10^{\circ}$ and $20^{\circ}$ for slope angle of $45^{\circ}$ and $55^{\circ}$. Moreover, $\beta_{\text {opt }}$ decreased with an increase of NS and $\alpha$ because the effect of nail inclination $(\beta)$ can only enhance the internal stability of slope.

- In terms of the effect of nail head size $\left(n_{h}\right)$, it yielded an increase in $\beta_{\text {opt }}$. This is due to the tensile force between the nail and nail head was perfectly confined to the soil in the active zone and also prevent the local failure on the slope surface.

- The conventional specification of $N S$ and $\beta$ suggested by Carlos et al. [4] and Phear et al. [18] was applicable on slope $45^{\circ}$ and $55^{\circ}$; however, it was inappropriate for slope $65^{\circ}$ and $75^{\circ}$, in which $n_{h}$ is required at least with the size of $0.4 \times 0.4 \mathrm{~m}, N S \leq 1.5 \mathrm{~m}$, and $5^{\circ} \geq \beta \geq 10^{\circ}$.

For the safe design of soil-nailed slope, the above-mentioned parameters need to be considered and further parametric study will also be needed for the other types of soil.

Acknowledgements

This research was supported by a grant (21RITD-C158631-02) from Regional Innovation Technology Development Program Funded by Ministry of Land, Infrastructure and Transport of Korean government.

Authors' contributions

All authors read and approved the final manuscript.

\section{Declarations}

Competing interests

The authors declare that they have no competing interests.

Received: 5 November 2020 Accepted: 15 June 2021

Published online: 02 November 2021

\section{References}

1. Adakani A, Bayat M, Javanmard M (2014) Numerical modeling of soil nail walls considering Mohr Coulomb, hardening soil and hardening soil with small-strain stiffness effect models. Geomech Eng 6(4):391-401. https://doi.org/10. 12989/gae.2014.6.4.391

2. Barley AD, Clayton CRI (1996) Soil nailing case histories and developments. Instit Civil Eng. https://doi.org/10.1680/ rs.19324.0056

3. BS 8006 (2010) Code of practice for Strengthened/reinforced soils and other fills. British Standards Institution, London 
4. Carlos AL, Helen R, Jesús EG, Andrew B, Allen C, Ryan B (2015) Soil nail walls-reference manual. Research Report No. FHWA-NHI-14-007. Department of Transportation Publication Federal Highway Administration, Washington DC

5. Chhun KT, Jang $\mathbb{H}$, Yune CY (2020) Probabilistic analysis of local instability between soil nails. Proc Civil Eng-Geotech. https://doi.org/10.1680/jgeen.19.00223

6. DTMR (2017) MRTS03 drainage, retaining structures and protective treatment. Department of Transportation and Main Roads, Brisbane

7. Fan CC, Luo JH (2008) Numerical study on the optimum layout of soil-nailed slope. Comput Geotech 35(4):585-599. https://doi.org/10.1016/j.compgeo.2007.09.002

8. Farzi M, Khodadadi R (2017) The effect of nail inclination angle on improving the performance of nailing system in vertical excavation. Civil Eng Res J 1(3):56-61. https://doi.org/10.19080/CERJ.2017.01.555561

9. FHWA (1993) French National Research Project Clouterre. Research Report No. FHWA-SA-93-026. Department of Transportation Publication Federal Highway Administration, Washington DC

10. GEO (2008) Guide to soil nail design and construction. Civil engineering and development department, Hong Kong

11. Guler E, Bozkurt CF (2004) The effect of upward nail inclination to the stability of soil nailed structure. Geotech Eng Transp Proj. https://doi.org/10.1061/40744(154)218

12. Hong CY, Yin JH, Zhou WH, Pei HF (2012) Analytical study on progressive pullout behavior of a soil nail. J Geotech Geoenviron Eng 138(4):500-507. https://doi.org/10.1061/(ASCE)GT.1943-5606.0000610

13. Hossain MA, Islam A (2016) Numerical analysis of the effects of soil nail on slope stability. Int J Comput App 141(8):12-15. https://doi.org/10.5120/IJCA2016908816

14. Johnson PE, Card GB, Darley P (2002) Soil nailing for slopes. Research Report No. 537. Transport Research Laboratory, Crowthorne

15. Kim Y, Lee S, Jeong S, Kim J (2013) The effect of pressure-grouted soil nails on the stability of weathered soil slopes, Comput Geotech 49:253-263. https://doi.org/10.1016/j.compgeo.2012.12.003

16. Lin H, Xiong W, Cao P (2013) Stability of soil nailed slope using strength reduction method. Eur J Environ Civil Eng 17(9):872-885. https://doi.org/10.1080/19648189.2013.828658

17. Pedley MJ, Pugh RS (1995) Soil nailing in the Hastings Beds. Eng Geol Con. https://doi.org/10.1144/GSL.ENG.1995. 010.01.32

18. Phear A, Dew C, Ozsoy B, Wharmby NJ, Judge J, Barley AD (2005) Soil nailing — best practice guidance. Construction Industry Research and Information Association, London

19. Rawat S, Gupta AK (2016) Analysis of a nailed soil slope using limit equilibrium and finite element methods. Int J Geosy Ground Eng. https://doi.org/10.1007/s40891-016-0076-0

20. Rotte VM, Viswanadham BVS, Chourasia D (2011) Influence of slope geometry and nail parameters on the stability of soil-nailed slopes. Int J of Geotech Eng 5(3):267-281. https://doi.org/10.3328/JJGE.2011.05.03.267-281

21. Shiu YK, Chang GWK (2004) Soil nail head review. Geo Report No. 175. Civil Eng and Development Department, Hong Kong

22. Shiu YK, Chang GWK (2005) Effects of inclination, length pattern and bending stiffness of soil nails on behavior of nailed structures. Geo Report No. 197. Civil Eng and Development Department, Hong Kong

23. Sivakumar Babu GL, Singh VP (2010) Reliability analyses of a prototype soil nail wall using regression models. Geomech Eng 2(2):71-88. https://doi.org/10.12989/gae.2010.2.2.071

24. Sivakumar Babu GL, Singh VP (2009) Simulation of soil nail structures using PLAXIS 2D. Plaxis Bull 25(3):16-21

25. Tang OL, Jiang QM (2015) Stability analysis of slope under different soil nailing parameters based on the GeoStudio. Int J Geohaz Environ 1(2):88-92. https://doi.org/10.15273/ijge.2015.02.010

26. Zhang M, Song E, Chen Z (1999) Ground movement analysis of soil nailing construction by three-dimensional (3-D) finite element modelling (FEM). Comput Geotech 25(4):191-204. https://doi.org/10.1016/S0266-352X(99)00025-7

27. Zhou YD, Cheuk CY, Tham LG (2009) Numerical modeling of soil nails in loose fill slope under surcharge loading. Comput Geotech 36(5):837-850. https://doi.org/10.1016/j.compgeo.2009.01.010

\section{Publisher's Note}

Springer Nature remains neutral with regard to jurisdictional claims in published maps and institutional affiliations.

\section{Submit your manuscript to a SpringerOpen ${ }^{\circ}$ journal and benefit from:}

- Convenient online submission

- Rigorous peer review

- Open access: articles freely available online

- High visibility within the field

- Retaining the copyright to your article

Submit your next manuscript at $\gg$ springeropen.com 